\title{
Pembaharuan Lembaga Pendidikan Islam di Pondok Pesantren
}

\author{
Meilisa Putri ${ }^{1}$, Ahmad Rivauzi ${ }^{2}$ \\ meilisaputri054@gmail.com¹, ahmadrivauzi@fis.unp.ac.id² \\ Universitas Negeri Padang1,2
}

\begin{tabular}{|c|c|}
\hline ART & \multirow{13}{*}{$\begin{array}{l}\text { This study aims to look at the renewal of Islamic } \\
\text { educational institutions in the Light-light Nurul Yaqin Islamic } \\
\text { Boarding School, which consists of foundations, formal and } \\
\text { non-formal institutions. This study uses a qualitative method } \\
\text { with a descriptive approach. Sources of data were taken } \\
\text { through direct interviews with informants consisting of the } \\
\text { Caliph, the Head of the Pondok, Deputy Curriculum for the } \\
\text { cottage, the Daily Executive of the El Imraniyah Islamic } \\
\text { Development Foundation, and the educators of the Nurul } \\
\text { Yaqin Islamic Boarding School. To strengthen the data, } \\
\text { researchers also took data through observation and } \\
\text { documentation. Overall, the results of the study showed that } \\
\text { the renewal of Islamiceducation in terms ofinstitutions atthe } \\
\text { Light-light Nurul Yaqin Islamic Boarding School did not } \\
\text { experience many changes, but in the formal institutions of } \\
\text { Islamic boarding schools officially made the Bustanul } \\
\text { Muahaqqiqin and Mudaqqiqin classes which were formerly } \\
\text { non-formal institutions, changed their status to the formal } \\
\text { institution in } 2021 \text { under the name Ma'had Aly. }\end{array}$} \\
\hline Article history: & \\
\hline Received, 09 Februari 2022 & \\
\hline Revised, 16 Februari 2022 & \\
\hline Acce & \\
\hline Keywords: & \\
\hline Pembaharuan, Lembaga & \\
\hline Pendidikan, Pendidikan & \\
\hline Islam & \\
\hline Clonflict of Interest: & \\
\hline None & \\
\hline Funding: & \\
\hline None & \\
\hline
\end{tabular}

Corresponding Author: Meilisa Putri, Department Islamic Education Faculty of Social Science Universitas Negeri Padang, Indonesia, Email: meilisaputri054@gmail.com, Phone No: $+6285375950830$

Copyright $(2022$, Author(s)

\section{Pendahuluan}

Pendidikan adalah suatu upaya yang dilakukan untuk pengembangan akhlak, keterampilan, dan pengetahuan untuk pemuda baik di sekolah maupun di rumah, sehingga mendapatkan hidup bahagia dan bermanfaat bagi bangsa dan negara (Musfah, 2015). Dapat dipahami bahwa pendidikan adalah pembinaan bagi anak-anak dalam hal akhlak, keterampilan dan pengetahuan, yang mana hal itu dilakukan secara sadar dan terencana agar mendapatkan kehidupan yang bermanfaat bagi bangsa dan negara.

Dalam pendidikan tentu harus dilakukan pembaharuan hal ini sangat penting dilakukan dalam rangka menyesuaikan pembelajaran dengan zaman yang berlangsung saat itu. Pembaharuan yang dimaksud tentu tidak hanya pembaharuan dari segi pendidikan umum saja, namun pendidikan Islam yang sudah lama berkembang di Indonesia ini pun juga harus selalu melakukan pembaharuan. Menurut Daulay dalam Rifai (2017) yang dimaksud pendidikan Islam adalah pendidikan yang bertujuan 
untuk menciptakan pribadi muslim seutuhnya, mengembangkan semua potensi insan baik yang berbentuk jasmani maupun rohani. Terkait dengan pendidikan Islam tentu harus ada lembaga yang menerapkan pembaharuan baik dari segi kelembagaan. Sebelum membahas tentang lembaga yang menerapkan pembaharuan, kita harus mengetahui apa itu kelembagaan, yang dimaksud dengan lembaga pendidikan adalah suatu tempat yang berfungsi untuk membina manusia, dan membawa ke arah masa depan yang lebih baik (Gazali,2013).

Oleh karena itu kelembagaan setiap tahunnya harus selalu mengalami perkembangan dan inovasi atau pembaharuan dimana inovasi-inovasi itu dilakukan untuk mendapatkan hasil terbaik dari pendidikan itu sendiri, dan tentunya setiap inovasi yang dilakukantidak lepas dari perkembangan zaman yang ada pada saat itu. Salah satu lembaga pendidikan yang harus melakukan pembaharuan dari segi kelembagaan yang bagus dan sesuai dengan perkembangan zaman adalah lembaga pesantren, hal ini dikarenakan lembaga pesantren nantinya akan menghasilkan santrisantri yang berintegritas dan berpemahaman akan agama yang bagus pula. Pesantren sendiri merupakan saksi bisu dari perkembangan pendidikan di Indonesia, hal ini dikarenakan, pesantren adalah lembaga tertua di Indonesia yang secara nyata telah melahirkan banyak ulama.

Istilah pesantren berasal dari Pe-"santri"-an, dimana kata santri berarti murid dalam bahasa jawa. Istilah pondok berasal dari bahasa Arab “Funduuq" yang berarti penginapan (Syafe'i, 2017). Hal yang membedakan pesantren dengan lembaga pendidikan lain pada umumnya di Indonesia adalah setiap peserta didik yang ingin menuntut ilmu di pesantren mereka diwajibkan untuk sekaligus menginap disana, hal ini tidak lain karena lembaga pesantren tidak hanya dikenal sebagai lembaga pendidikan kognitif tentang ajaran Islam maupun ilmu pengetahuan umum saja, tetapi pesantren juga dikenal dengan tempat untuk pembentukan karakter bagi santrisantrinya.

Dalam hal ini pesantren sebagai institusi tertua dan pencetak generasi pemimpin dan ulama harus bisa melahirkan generasi-generasi yang tidak hanya fokus akan permasalahan agama saja, namun juga bisa melahirkan generasi yang cakap akan teknologi dan informasi yang sesuai dengan perkembangan zaman, sehingga generasi yang dilahirkan tidak akan ketinggalan dari yang lain, baik dari segi ilmu pengetahuan umum maupun agamanya, sehingga nantinya mampu untuk bersaing dalam dunia global.

Pondok pesantren Nurul Yaqin Ringan-ringan merupakan pondok pesantren yang memiliki ciri khas akan kemahiran santri-santrinya dalammembaca kitab gundul, dengan corak pesantren yang salafiyah (tradisional). Berdasarkan penelitian Riri Nurmalasari pada tahun (2014) dalam disertasinya menjelaskan bahwa Pondok Pesantren Nurul Yaqin Ringan- ringan telah mengalami banyak perkembangan dari awal pondok pesantren ini berdiri yaitu dari tahun 1960. Perkembangan yang dimaksud oleh Riri dalam disertasinnya adalah pada awal pendirian Pondok Pesantren Nurul Yaqin Ringan-ringan ini belum memiliki kurikulum pendidikan dan sarana prasaranayang digunakan untuk belajar dulu hanya dilakukan di Surau, namun seiring perkembangan zaman Pondok Pesantren Nurul Yaqin Ringan-ringan telah mempunyai ruang kelas untuk belajar dan juga memiliki asrama untuk santri yang merupakan bantuan dari pemerintah. 
Meilisa Putri dan Ahmad Rivauzi: Pembaharuan Lembaga Pendidikan Islam di Pondok...

Dengan adanya pembaharuan yang dilakukan oleh Pondok Pesantren Nurul Yaqin Ringan-ringan setelah meninggalnya buya Ali Imran dari segi Sistem Kelembagaan, maka dari itu penulis memberikan judul penelitian ini dengan "Pembaharuan Lembaga Pendidikan Islam Di Pondok Pesantren Nurul Yaqin Ringan-Ringan Pakandangan Kabupaten Padang Pariaman."

\section{Tinjauan Pustaka}

Secara bahasa, kata tajdid berarti pembaharuan. Dalam bahasa Arab, sesuatu dikatakan "jadid" (baru), jika bagian-bagiannya masih erat menyatu dan masih jelas. Harun Nasution dalam (Rifai, 2017) menyebutkan bahwa gerakan pembaharuan pemikiran Islam dengan sebutan modernisasi pemikiran Islam yang mempunyai arti, seperti suatu aliran, gerakan, pemikiran, dan usaha untuk mengubah paham, adat istiadat agar semuanya disesuiakan dengan pendapat dan keadaan baru yang timbul oleh kemajuan ilmu pengetahuan serta teknologi modern.

Menurut Azyumardi Azra dalam (Basyit, 2017) menyebutkan bahwa pesantren dan madrasah adalah salah satu lembaga pendidikan Islam yang mengalami perubahan yang cepat dan luas, sekitar pada dua dasawarsa terakhir. Perubahan tersebut terlihat pada kelembagaan dan substansi keilmuan. Selama ini, pesantren seringkali dicap sebagai lembaga pendidikan yang tradisional serta dibarengi dengan pandangan bahwa pesantren sering diasosiasikan dengan keterbelakangan dalam segala hal: fasilitas, teknologi, metode pembelajaran, dan bahkan kurikulumnya (Noor, 2018). Tata kelola bangunan pesantren pun pada umumnya jauh dari keteraturan, begitu juga para santrinya yang acapkali kudisan karena jarang menjaga kebersihan. Gaya berpakaian santri yang identik dengan sarung juga acap menjadi legitimasi mencap santri sebagai kaum tradisional.

Namun demikian, penyematan tradisional terhadap pesantren agaknya tidak lagi relevan untuk saat ini. Perkembangan pembaharuan yang ditandai dengan lajunya perkembangan teknologi telah menuntut pesantren untuk melakukan penyesuaian diri. Tak sedikit pesantren yang melakukan perubahan dari yang paling mendasar, baik dari segi metode pembelajaran, kurikulum, maupun pola kepemimpinan. Pesantren pun tak lagi terkonsentrasi di pedesaan, tapi sudah tersebar secara sporadis di berbagai kota besar dan menjadi tujuan pendidikan masyarakat urban. Berikut pembaharuan yang ada di pondok pesantren:

\section{Pembaharuan Kelembagaan Pendidikan Madrasah atau Pondok Pesantren}

Pondok pesantren yang merupakan lembaga pendidikan Islam mapan dan juga lembaga yang masih berperan aktif membina sosio-budaya bangsa, terutama untuk mereka yang dididik di dalamnya, sampai saat ini lembaga tersebut masih menunjukkan kemampuannya untuk memelihara nilai-nilai luhur ajaran Islam, sehingga menjadi modal utama yang sangat penting bagi pesantren (Fadhilah, 2011). berikut lembaga-lembaga yang ada di pondok pesantren:

Dalam pondok pesantren lembaga yang dimaksud adalah yayasan, yang dimaksud dengan adalah suatu badan hukum yang didirikan sebagai alat untuk memberikan bantuan dalam mencapai tujuan sosial. Subekti dalam (Sumarni, 2018) mengartikan 
yayasan sebagai badan hukum yang berada dibawah pimpinan suatu badan pengurus dengan tujuan sosial dan tujuan tertentu yang legal.

Sedangkan pengertian yayasan menurut Undang Undang yayasan No No. 28 Tahun 2004 tentang Perubahan atas Undang-Undang Nomor 16 Tahun 2001, yayasan adalah badan hukum yang memiliki kekayaan terpisah dan digunakan untuk mencapai tujuannya di bidang agama, sosial, dan kemanusiaan, serta tidak memiliki anggota. Dalam rangka melaksanakan kegiatannya, yayasan hanya memiliki organ yang terdiri dari Pembina, pengurus, dan pengawas.

Ketua yayasan dalam sebuah lembaga pendidikan berfungsi dan bertanggung jawab mengkoordinir semua kegiatan proses pendidikan dan pembelajaran demi terwujudnya visi dan misi lembaga (Muda, 2019). Peran yayasan dalam mengelola penyelenggaraan pendidikan swasta sangat banyak antara lain: (1) Mempercayakan pengelolaan pelaksanaan praktek pendidikan terbaik pada kepala sekolah dan guru, (2) Menjadi pihak yang memikirkan pengembangan dan menentukan arah dari pengembangan sekolah yang kemudian dikonsultasikan saat rapat dengan komite sekolah (Penentuan visi, orientasi, platform program dan kebijakan dasar sekolah), (3) Memberikan perhatian pada upaya pemberian kesempatan pada siswa berprestasi bisa lewat pemberian beasiswa dan lain sebagainya, (5) Memberikan support pada upaya sekolah memajukan diri lewat Teknologi Informasi atau sarana prasarana yang diperlukan oleh sekolah sebagai sebuah institusi, (6) Memikirkan sumber pendanaan agar kegiatan sekolah bisa dilaksanakan dengan baik serta guru mendapat support untuk melakukan proses kegiatan pembelajaran yang kreatif dan menarik di sekolah, (7) Pengendali pengelolaan sekolah (Sumarni, 2018).

Tidak hanya memiliki peran, yayasan juga memiliki fungsi dalam sebuah lembaga pendidikan, Menurut UU No 28 Tahun 2004 tentang yayasan, beberapa fungsi yayasan dalam penyelenggaraan pendidikan antara lain: (1) Menyelenggarakan lembaga pendidikan sejak proses perijinan, (2) Menetapkan visi, orientasi, platform program dan kebijakan sekolah, (3) Menyeleksi, mengangkat dan memberhentikan tenaga pengelola sekolah, (4) Menyediakan sarana, prasarana dan pembiayaan sekolah, (5) Memberikan pertimbangan dan persetujuan terhadap rencana program pengelolaan sekolah, (6) Mengesahkan program dan anggaran sekolah, (7) Mengawasi dan mengendalikan proses pengelolaan sekolah, (8) Menilai kinerja dan tanggung jawab pengelola sekolah, (9) Memutuskan batas-batas kerjasama sekolah dengan pihak luar, (10) Bertanggung jawab atas kepengurusan, kepentingan dan tujuan yayasan, (11) Bertanggung jawab di berhadapan pengadilan, (12) Bertanggung jawab penuh terhadap pengelolaan unit-unit yayasan, (13) Menanggung kerugian unit kegiatan yang disetujui oleh yayasan kepada pihak ketiga.

Pendidikan formal adalah Lembaga pendidikan yang terstruktur dan berjenjang yang terdiri atas pendidikan dasar, pendidikan menengah, dan pendidikan tinggi (Darlis, 2017). Dari pengertian tersebut dapat kita ambil kesimpulan bahwa yang dimaksud dengan lembaga pendidikan formal adalah lembaga pendidikan yang terstruktur dan berjenjang. Dalam islam Taofik (2020) membagi jenjang pendidikan formal ini kepada 3 jenjang pendidikan, yaitu pendidikan dasar, menengah dan tinggi:

Lembaga Pendidikan Islam Formal Jenjang Pendidikan Dasar di antaranya yaitu Taman Kanak-Kanak (TK) Islam Terpadu, Raudhatul Athfal, Sekolah Dasar Islam Terpadu/Boarding School, Madrasah Ibtidaiyah (MI), Sekolah Menengah Pertama 
Meilisa Putri dan Ahmad Rivauzi: Pembaharuan Lembaga Pendidikan Islam di Pondok...

(SMP) Islam Terpadu/Boarding School, dan Madrasah Tsanawiyah (MTs). Lembaga PendidikanIslam Formal Jenjang Pendidikan Menengah di antaranya yaitu Sekolah Menengah Atas (MA) Islam Terpadu/Boarding School, Madrasah Aliyah (MA), dan Sekolah Menengah Kejuruan (SMK) Islam terpadu/Boarding School. Lembaga Pendidikan Islam Formal Jenjang Pendidikan Tinggi di antaranya yaitu Akademi, Politeknik, Sekolah Tinggi, Institut, dan Universitas.

Pendidikan selanjutnya yaitu nonformal adalah jalur pendidikan di luar pendidikan formal yang dapat dilaksanakan secara terstruktur dan berjenjang (Darlis, 2017). Khusus untuk pendidikan agama dan keagamaan telah diatur dalam peraturan pemerintah No 55 Tahun 2007 tentang pendidikan agama dan keagamaan. Untuk pendidikan keagamaan Islam terdapat dalam pasal 21 ayat 1 yang menyatakan bahwa pendidikan diniyah nonformal diselenggarakan dalam bentuk pengajian kitab, majelis taklim, pendidikan Alquran, diniyah takmiliyah, atau bentuk lain yang sejenis.

Menurut UU No 20 Tahun 2003 pendidikan non formal ialah jalur pendidikan yang tujuannya untuk mengganti, menambah dan melengkapi pendidikan formal. Pendidikan ini dapat diselenggarakan oleh lembaga khusus yang ditunjuk oleh pemerintah dengan berpedoman pada standar nasional pendidikan. Dan karena berpedoman pada standar nasional pendidikan maka hasil dari pendidikan non formal tersebut dapat dihargai setara dengan pendidikan formal. Selain itu lembaga pendidikan non formal juga dapat berasal dari program pembelajaran yang tumbuh dan berkembang di Masyarakat.

Berikut beberapa contoh lembaga pendidikan islam non formal seperti lembaga kursus, lembaga pelatihan, kelompok belajar, pusat kegiatan belajar masyarakat, majelis taklim, dan satuan pendidikan sejenis: Pesantren, Day Care, Bimbingan Belajar.

\section{Metode}

Jenis Penelitian yang penulis gunakan adalah field research atau penelitian kualitatif yang bersifat deskriptif (Sugiyono, 2012). Metode penelitian yang digunakan yaitu metode observasi, metode wawancara dan metode dokumentasi. Adapun yang menjadi informan dalam penelitian diantaranya: a) Khalifah Pondok Pesantren Nurul Yaqin Ringan-ringan, b) Pimpinan Pondok Pesantren Nurul Yaqin Ringan-ringan, c) Wakil Kesiswaan Pondok Pesantren Nurul Yaqin Ringan-ringan, d) dan Tenaga Pendidik (Tendik) Pondok Pesantren Nurul Yaqin Ringan-ringan. Teknik analisis data dalam penelitian ini menggunakan deduktif, keterangan-keterangan yang bersifat umum menjadi pengertian khusus yang terperinci, baik dari pengetahuan yang diperoleh dari lapangan maupun kepustakaan. Teknik pengabsahan data menggunakan triagulasi sumber data (Jaya, 2020).

\section{Hasil dan Pembahasan}

Data yang disajikan disini merupakan hasil penelitian di lapangan teknik-teknik pengumpulan data yang telah ditetapkan yaitu melalui wawancara, observasi dan dokumentasi. Berikut peneliti sajikan hasil dan pembahasan dari pembaharuan sistem kelembagaan yang ada di pondok pesantren Nurul Yaqin Ringan-ringan.

Berdasarkan hasil penelitian yang merupakan wawancara peneliti dengan TK. Syafwul Bary sebagai pengurus harian Yayasan Pembangunan Islam El Imraniyah (YPII) dan Menurut Undang Undang yayasan No No. 28 Tahun 2004 tentang Perubahan atas Undang-Undang Nomor 16 Tahun 2001, yayasan adalah badan hukum yang 
memiliki kekayaan terpisah dan digunakan untuk mencapai tujuannya di bidang agama, sosial, dan kemanusiaan, serta tidak memiliki anggota. Dan dalam Undangundang tersebut juga dijelaskan bahwa yayasaan berfungsi sebagai (1) Menyelenggarakan lembaga pendidikan sejak proses perijinan, (2) Menetapkan visi, orientasi, platform program dan kebijakan sekolah, (3) Menyeleksi, mengangkat dan memberhentikan tenaga pengelola sekolah, (4) Menyediakan sarana, prasarana dan pembiayaan sekolah, (5) Memberikan pertimbangan dan persetujuan terhadap rencana program pengelolaan sekolah, (6)Mengesahkan program dan anggaran sekolah, (7)Mengawasi dan mengendalikan proses pengelolaan sekolah, (8) Menilai kinerja dan tanggung jawab pengelola sekolah, (9)Memutuskan batas-batas kerjasama sekolah dengan pihak luar, (10) Bertanggung jawab atas kepengurusan, kepentingan dan tujuan yayasan, (11) Bertanggung jawab di berhadapan pengadilan, (12) Bertanggung jawab penuh terhadap pengelolaan unit-unit yayasan, (13) Menanggung kerugian unit kegiatan yang disetujui oleh yayasan kepadapihak ketiga.

Jika kita lihat dari peran yayasan yang ada dalam undang-undang peran Yayasan Pembangunan Islam El- Imtaniyah (YPII) di Pondok Pesantren Nurul Yaqin Ringanringan adalah sebagai lembaga yang menaungi tujuannya dibidang agama, karena lembaga yang dinaungi oleh YPII adalah pondok pesantren. Dan berdasarkan hasil penelitian juga fungsi dari YPII adalah sebagai pihak yang mengatur sarana prasarana pondok dan sebagai pihak yang menjadi jembatan bagi pondok untuk mencari lembaga-lembaga lain yang bisa dijadikan mitra atau kerjasama dalam berbagai hal. Dan terkait pembaharuan dari segi fungsi pada yayasan di pondok pesantren Nurul Yaiqn Ringan-ringan ini tidak mengalami perubahan atau pun pembaharuan setelah buya Ali Imran Meninggal.

Namun perubahan yang paling mencolok adalah dari segi strutur pendiri dari lembaga Yayasan Pendidikan Islam el Imraniyah ini, yaitu setelah meninggalnya buya Ali Imran yang mana buya berkedudukan sebagai Pendiri yayasan, namun setelah beliau meninggal nama beliau dihilangkan sebagai pendiri yayasan, berikut penulis lampirkan SK Yayasan Pembangunan Islam El Imraniyah :

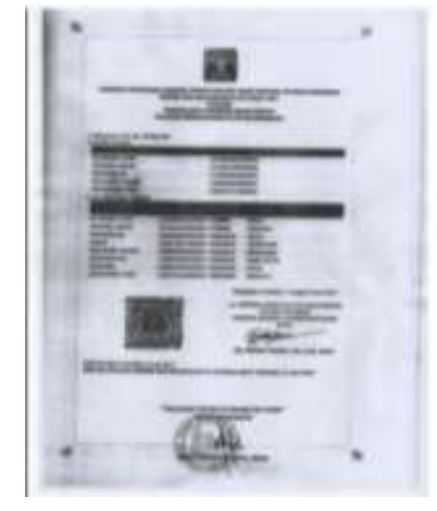

Gambar 1. SK Yayasan Pembangunan Islam El Imraniyah

Pendidikan formal adalah Lembaga pendidikan yang terstruktur dan berjenjang yang terdiri atas pendidikan dasar, pendidikan menengah, dan pendidikan tinggi (Darlis, 2017). Dalam Islam Taofik (2020) membagi jenjang pendidikan formal ini kepada 3 jenjang pendidikan, yaitu pendidikan dasar, menengah dan tinggi.

Berdasarkan hasil penelitian pembaharuan yang terjadi di lembaga pendidikan formal di pondok pesantren Nurul YaqinRingan-ringan adalah dengan diresmikannya 
Meilisa Putri dan Ahmad Rivauzi: Pembaharuan Lembaga Pendidikan Islam di Pondok...

kelas Bustanul Muhaqqiqin dan Mudaqqiqin menjadi lembaga formal yang setingkat dengan S1, hal ini dikarenakan ketersediaannya berbagai fasilitas belajar baik itu ruang belajar, tenaga pendidik dan fasilitas lainnya yang membuat Ma'had Aly layak untuk didirikan daam lingkungan Pondok Pesantren Nurul Yaqin Ringan-ringan. Hal ini juga membuktikan bahwa pendidikan di pondok pesantren Nurul Yaqin Ringan-ringan terus melakukan upaya-upaya pengembangan dan pembaharuan. Berikut penulis lampirkan surat pernyataan pendirian Ma'had Aly Nurul Yaqin Ringan-ringan:

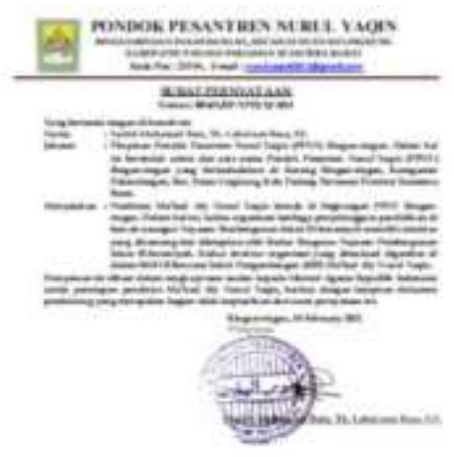

Gambar 2. Surat Pendirian Ma'had Aly Nurul Yaqin Ringan-ringan Pernyaan

Pendidikan nonformal adalah jalur pendidikan diluar pendidikan formal yang dapat dilaksanakan secara terstrukturdan berjenjang (Darlis, 2017). Menurut UU No 20 Tahun 2003 pendidikan non formal ialah jalur pendidikan yang tujuannya untuk mengganti, menambah dan melengkapi pendidikan formal.

Berdasaarkan hasil penelitian lembaga non formal di pondok pesantren Nurul Yaqin Ringan-ringan adalah pembelajaran yang membahas tentang Tarekat dan Keagamaan, lembaga ini tidak mengalami banyak perubahan selain dalam bentuk perapian dan penambahan kajian-kajian namun tetap tidak melenceng dari apa yang telah diajarkan oleh Buya Ali Imran. Dan pembaharuan yang dilakukan di lembaga non formal ini adalah penayangan aktifitas kajian secara live streaming sehingga masyarakat luar bisa mengikuti pembelajaran yang sedang berlangsung. Sebagai penjabaran yang lebih jelas, berikut penulis sajikan bagan strutur lembaga yang ada di pondok pesantren Nurul Yaqin Ringan-ringan:

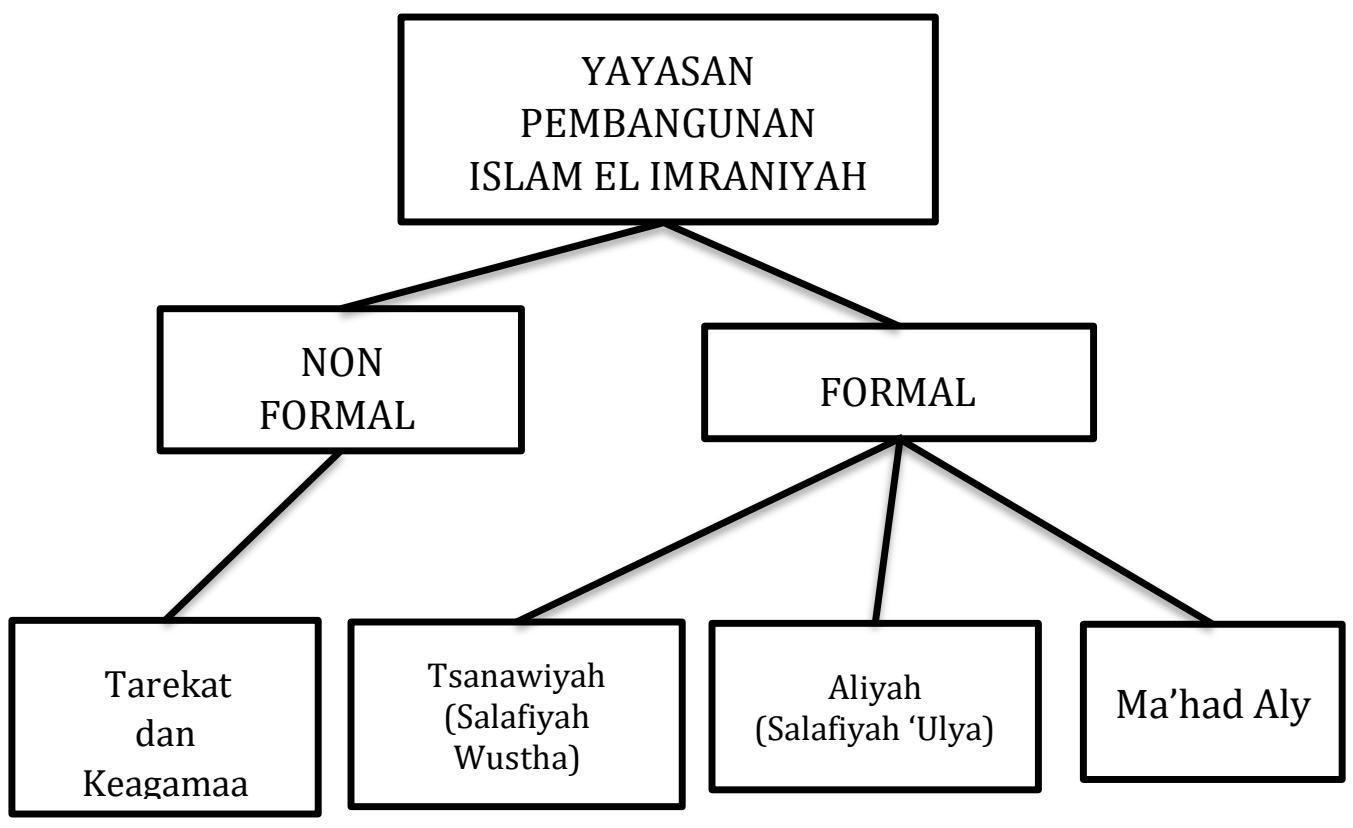


Gambar 3. Struktur Kelembagaan di Pondok Pesantren Nurul Yaqin Ringan-Ringan

Berdasarkan bagan di atas dapat kita lihat bahwa lembaga tertinggi yang ada di pondok pesantren Nurul Yaqin Ringan-ringan adalah yayasan yang berperan sebagai lembaga yang menaungi pondok pesantren Nurul yaiqn Ringan-ringan, baik dari segi sarana prasarana, dan lain sebagainya. Dan lembaga selanjutnya yaitu lembaga pendidikan formal yang menaungi satuan pendidikan tingkat Aliyah dan Tsanawiyah dan Ma'had Aly. Dan terakhir yaitu lembaga pendidikan non formal yang berperan sebagai lembaga yang menaungi pembelajaran Tarekat dan keagamaan, lembaga ini tidak memiliki jenjang yang khusus dan hanya diwajibkan bagi santri kelas 7 sedangkan bagi santri dari kelas 1-6 boleh memilih untuk mengikuti pembelajaran tarekat ini atupun tidak.

\section{Simpulan}

Yayasan Pembangunan Islam el Imraniyah (YPII) baru berdiri semenjak tahun 1960 yang dilatar belakangi oleh keinginan salah satu anak dari buya Ali Imran yaitu Drs. Idarussalam Tk.Sutan yang ingin pondok pesantren Nurul Yaqin Ringan-ringan agar pondok pesantren menjadi lebih formal dan terstruktur dan dinamai dengan Yayasan pembangunan Islam el Imraniyah yang diambil dari nama buya Ali Imran. Semenjak berdirinya peran yayasan bagi pondok pesantren adalah sebagai lembaga yang menaungi dan mengembangkan pondok pesantren dan tidak ada perubahan yang terlalu signifikan kecuali di awal berdirinya yayasan mengubah tata cara belajar di pondok yaitu dari sistem halaqah menjadi klasikal dan mulai menggunakan meja, seragam, sistem penilaian, ujian, pemberian rapor dan ijazah.

Lembaga formal yang ada di pondok pesantren Nurul yaqin Ringan-ringan adalah Madrasah Aliyah (Salafiyah Ulya) dan Madrasah Tsanawiyah (Salafiyah Wustha), dan yang terbaru seara resmi pondok pesantren Nurul Yaqin Ringan-ringan juga membuka Ma'had Ali dengan Jurusan Tarekat dan Tasauf, yang mana sebelumnya nama kelas dari Ma'had Ali ini adalah Bustanul Muhaqqiqin dan Bustanul Mudaqqiqin. Dari segi peran tidak ada pembaharuan yang terjadi di lembaga pendidikan formal, perannya tetap sama yaitu menyelenggarakan pendidikan yang terdiri dari 3 tingkat yaitu Madrasah Aliyah (Salafiyah Ulya), Madrasah Tsanawiyah (Salafiyah Wustha) dan Ma'had Ali. Lembaga non formal yang ada di pondok pesantren Nurul Yaqin Ringan-ringan adalah lembaga yang menaungi pembelajaran Terekat Syattariah, kelas tarekat ini hanya ada setiap senin dan rabu dan hanya wajib diikuti oleh santri yang berada pada tingkatan kelas 7 sedangkan santri yang berada pada kelas 1-6 boleh memilih apakah ingin mengikuti kelas ini atau tidak. Sejauh ini tidak ada pembaharuan yang terjadi di pembelajaran tarekat.

\section{Referensi}

Al-Tadzkiyyah: Jurnal Pendidikan Islam, 8(1), 61-82.

Basyit, A. (2017). Pembaharuan model pesantren: respon terhadap modernitas. Kordinat: Jurnal Komunikasi Antar Perguruan Tinggi Agama Islam, 16(2), 293 324. 
Meilisa Putri dan Ahmad Rivauzi: Pembaharuan Lembaga Pendidikan Islam di Pondok...

Darlis, A. (2017). Hakikat Pendidikan Islam: Telaah Terhadap Hubungan Pendidikan Informal, Non Formal dan Formal. Jurnal Tarbiyah, 24(1).

Fadhilah, A. (2011). Struktur dan Pola kepemimpinan kyai dalam pesantren di Jawa. Hunafa: Jurnal Studia Islamika, 8(1), 101-120.

Jaya, I. M. L. M. (2020). Metode Penelitian Kualitatif dan Kuantitatif (F. Husaini (ed); pertama) QUADRANT.

Muda, L. (2019). Kepemimpinan ketua yayasan dalam mewujudkan kualitas pendidikan dan pembelajaran di SD swasta. Tadbir: Jurnal Manajemen Pendidikan Islam, 7(1), 1-10.

Musfah, J. (2015). Manajemen Pendidikan. Jakarta: Prenadamedia Group.

Noor, W. (2018). Pembaharuan Pesantren: Arah dan Implikasi. Edugama: Jurnal Kependidikan dan Sosial Keagamaan, 4(1), 67-84.

Rifai, A. S. (2017). Pembaharuan Pendidikan Pesantren Dalam Menghadapi Tantangan dan Hambatan di Masa Modern. INSPIRASI: Jurnal Kajian dan Penelitian Pendidikan Islam, 1(1), 21-38.

Riri, N. (2014). Perkembangan Pondok Pesantren Nurul Yaqin Ringan-ringan Pakandangan Kecamatan Enam Lingkuang Kabupaten Padang Pariaman (19602014) (Doctoral dissertation, STKIP PGRI Sumatera Barat).

Sugiyono, P. D. (2012). Metode Penelitian Pendidikan: Pendekatan Kuantitatif, Kualitatif, R\&D (Cetakan Ke 17). Bandung: CV Alfabeta.

Sumarni, M. S. (2018). Peran dan Fungsi Yayasan dalam Pengelolaan Pendidikan Madrasah. Edukasi, 16(2), 294535

Syafe'i, I. (2017). Pondok pesantren: Lembaga pendidikan pembentukan karakter.

Taofik, A. (2020). Lembaga Pendidikan Islam di Indonesia. Indonesian Journal of Adult and Community Education, 2(2) 